\title{
ANALISA RANTAI PASOK MATERIAL USAHA JASA KONSTRUKSI KABUPATEN TASIKMALAYA
}

\author{
Wahyu Teri Aripin ${ }^{1}$, Ernawati ${ }^{2}$, Igo Sumarli ${ }^{3}$ \\ 1,2,3 Sekolah Tinggi Teknologi Cipasung \\ ${ }^{1}$ wahyu@sttcipasung.ac.id \\ 2ernawati@sttcipasung.ac.id \\ 3igosumarli@gmail.com
}

\begin{abstract}
Abstrak - Pelaksanaan pekerjaan infrastruktur/jasa konstruksi di Kabupaten Tasikmalaya diketahui mengalami beberapa kendala, antara lain pada setiap tahun anggaran terdapat proyek yang mengalami keterlambatan penyelesaian sehingga harus dikenai denda keterlambatan. Dari hasil observasi keterlambatan penyelesaian beberapa proyek tersebut diakibatkan adanya hambatan pada rantai pasok, baik itu rantai pasok bahan baku, tenaga terampil dan perlengkapan. Hambatan ini disinyalir karena perencanaan supply chain yang kurang baik dari semua pihak yang terlibat dalam pengerjaan proyek tersebut. Tujuan dari kajian ini adalah untuk memberikan usulan terhadap pengelolaan rantai pasok usaha jasa konstruksi dalam rangka meningkatkan efisiensi dan efektivitas penyelenggaraan usaha jasa konstruksi di Kabupaten Tasikmalaya. Metode atau tahapan serta program kerja penyelesaian kegiatan Kajian Rantai Pasok Usaha Jasa Konstruksi di Kabupaten Tasikmalaya, akan diuraikan rencana rinci dimulai dari tahapan penyelesaian kegiatan yang akan menghubungkan beberapa variabel sistem rantai pasok usaha jasa konstruksi yang ada di Kabupaten Tasikmalaya. Penelitian ini hanya berfokus pada analisa rantai pasok materialnya saja. Data dikumpulkan melalui observasi, survei, dan wawancara dengan para stakeholders usaha jasa konstruksi di Kabupaten Tasikmalaya. Kemudian untuk validasi data dilakukan FGD sebelum akhirnya dilakukan pengolahan data. Hasil analisa menunjukkan bahwa bahan/material terutama jenis bahan tambang alam/quarry untuk infrastruktur di Kabupaten Tasikmalaya dengan mempertimbangkan permintaan secara keseluruhan diperkirakan akan mengalami defisit pasokan sekitar tahun 2028. Selain itu bentuk rantai pasok yang tidak ideal menjadi faktor terjadinya keterlambatan penyelesaian proyek pekerjaan konstruksi di Kabupaten Tasikmalaya. Sehingga dalam kajian ini dibuat rekomendasi rantai pasok yang ideal dari hasil kolaborasi rantai pasok ideal O’Brien untuk diterapkan pada usaha jasa konstruksi di Kabupaten Tasikmalaya.
\end{abstract}

Kata kunci : rantai pasok, usaha jasa konstruksi, material

Abstract - The implementation of infrastructure works / construction services in Tasikmalaya Regency is known to experience several constraints, including in every budget year there are projects that are late in completion so they must be subject to late fees. Based on the results of observations, the delay in the completion of some of the projects due to obstacles in the supply chain, both the supply chain of raw materials, skilled workers and equipment. This obstacle was allegedly due to poor supply chain planning from all parties involved in the work on the project. The purpose of this study is to provide a proposal for the management of the supply chain of construction service businesses in order to improve the efficiency and effectiveness of the implementation of its service in Tasikmalaya Regency. Methods or stages as well as work programs for completing Construction Service Business Supply Chain Study activities in Tasikmalaya Regency will be elaborated starting from the stage of completing activities that will connect several supply chain system construction service business variables in Tasikmalaya Regency. This research only focuses on analyzing the supply chain of the material. Data was collected through observations, surveys and interviews with stakeholders of the construction service business in Tasikmalaya Regency. Then the data validation is done by the FGD before data processing is finally performed. The results of the analysis show that the materials, especially the type of natural mining / quarry for infrastructure in Tasikmalaya Regency by considering the overall demand is expected to experience a supply deficit around 2028. Besides the non-ideal supply chain shape is a factor in the delays in the completion of construction work projects in Tasikmalaya Regency. So in this study an ideal supply chain recommendation was made from the results of the O'Brien's ideal supply chain collaboration to be applied to the construction service business in Tasikmalaya Regency.

Keywords : supply chain, construction services business, materials.

\section{PENDAHULUAN}

Pekerjaan konstruksi menurut Undang-undang No. 2 Tahun 2017 bab 1 pasal 1 ayat 3 adalah keseluruhan atau sebagian kegiatan yang meliputi pembangunan, pengoperasian, pemeliharaan, pembongkaran, dan pembangunan kembali suatu bangunan. Pada pelaksanaan proses produksi industri konstruksi membutuhkan keterlibatan banyak ahli, dikarenakan pekerjaannya kompleks, sehingga akan membentuk rantai pasok (supply chain) yang kompleks pula. Kompleksitas tersebut membutuhkan manajemen pengelolaan hubungan antar mata rantai yang terlibat. Hal ini diperlukan supaya dapat meningkatkan daya 
saing suatu perusahaan konstruksi di tengah semakin ketatnya persaingan.

Untuk dapat bersaing, struktur industri konstruksi Indonesia harus diperbaiki, agar lebih efisien dan efektif, kemampuan dalam mengelola usaha konstruksi, serta kapasitas individu pekerja dan profesional konstruksi harus ditingkatkan. Selain itu, industri konstrukdi harus memperbaiki koordinasi antar pihak yang terlibat, memperkuat pengendalian, mencegah terjadinya keterlambatan pasokan, dan memerbaiki metode kerja.

Dalam proses konstruksi sering terjadi inefisiensi dan sering menjadi kendala yang akan mempengaruhi kinerja kontraktor (Vrijhoef dan Koskela, 1999). Untuk mengurangi permasalahan dalam pelaksanaan proyek diperlukan pengelolaan rantai pasok konstruksi yang baik. Rantai pasok konstruksi yang baik akan meningkatkan kinerja kontraktor dalam melaksanakan suatu proyek. Salah satu strategi untuk mencapai rantai pasok konstruksi yang baik adalah manajemen rantai pasok konstruksi.

Dewasa ini, harapan konsumen (Pemerintah dan masyarakat) terhadap hasil produk konstruksi meningkat, menyebabkan semakin ketatnya persaingan antar perusahaan penyedia jasa konstruksi. Gambar 1 merupakan gambaran salah satu tren proyek bidang bangunan di Kabupaten Tasikmalaya yang memiliki kecenderungan selalu naik setiap tahunnya.

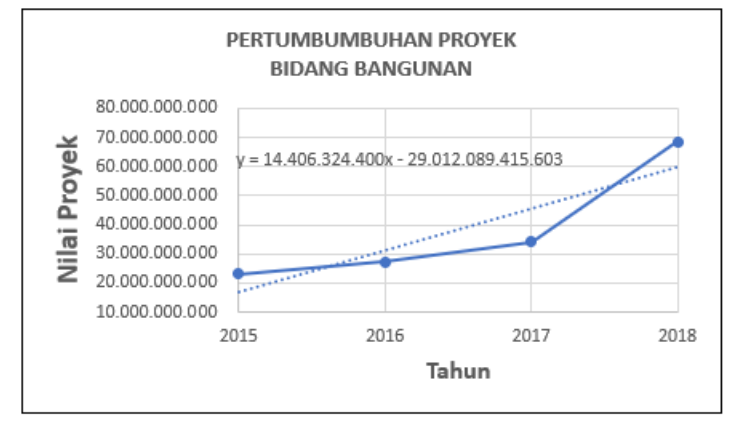

Gambar 1. Tren Proyek Bidang Bangunan Kabupaten Tasikmalaya

Hal tersebut membuat para penyedia jasa konstruksi lebih meningkatkan kinerja operasi perusahaan agar dapat menyesuaikan keinginan konsumen.

Selain itu, menurut Sekretaris Dinas PUPR Kabupaten Tasikmalaya jumlah kontraktor tidak sesuai dengan jumlah proyek yang ada. Sehingga kondisi tersebut memicu semakin ketatnya persaingan diantara penyedia jasa konstruksi. Akan tetapi, kondisi tersebut memperkuat posisi bargaining bagi pengguna jasa konstruksi dalam menentukan penyedia jasa yang paling tepat untuk menyediakan berbagai kebutuhan proyek. Untuk menghadapi tantangan tersebut, maka kerjasama yang saling menguntungkan harus terjalin antar pihak yang terlibat, sehingga ketentuan kualitas dan tenggat waktu pelaksanaan dapat terpenuhi.
Berdasarkan data dari Dinas PUPR Kabupaten Tasikmalaya, pelaksanaan pekerjaan infrastruktur/ jasa konstruksi di Kabupaten Tasikmalaya diketahui mengalami beberapa kendala, antara lain pada setiap tahun anggaran terdapat proyek yang mengalami keterlambatan penyelesaian sehingga harus dikenai denda keterlambatan. Sebagai contoh, proyek Renovasi Mesjid Agung Kabupaten Tasikmalaya yang belum selesai hingga akhir tahun 2018 dan proyek Pembangunan Jalan Ciawi Singaparna yang sudah mangkrak bertahun-tahun lamanya. Dari hasil observasi dan wawancara kepada Sekretaris Dinas PUPR Kabupaten Tasikmalaya, keterlambatan penyelesaian beberapa proyek tersebut diakibatkan adanya hambatan pada rantai pasok. Hambatan yang terjadi pada rantai pasok ini disinyalir karena perencanaan supply chain yang kurang baik dari semua pihak yang terlibat dalam pengerjaan proyek tersebut.

Dalam rangka meningkatkan efisiensi dan efektivitas usaha jasa konstruksi di Kabupaten Tasikmalaya perlu dibangun strategi pengelolaan rantai pasok usaha jasa konstruksi dengan baik.

\section{KAJIAN PUSTAKA}

Rantai pasok terbentuk dari sebuah perhubungan organisasi, sumber dan proses yang menciptakan serta mengirimkan produk dan jasa kepada pemakai akhir. Sebuah rantai pasok mencakup semua fasilitas, fungsi dan aktivitas yang terlibat dalam produksi dan pengiriman sebuah produk atau jasa dari para supplier ke konsumen. (Russel dan Taylor, 2000). Rantai pasok memiliki sifat yang dinamis namun melibatkan tiga aliran yang konstan, yaitu aliran informasi, produk dan uang. Disamping itu, tujuan utama dari setiap rantai pasok adalah untuk memenuhi kebutuhan konsumen dan menghasilkan keuntungan. (Chopra and Meindl, 2007). Rantai pasok lebih menekankan pada semua aktivitas dalam memenuhi kebutuhan konsumen yang di dalamnya terdapat aliran dan transformasi barang mulai dari bahan baku sampai ke konsumen akhir dan disertai dengan aliran informasi dan uang. (Ling Li, 2007). Rantai pasok terdiri dari rangkaian pihak-pihak yang dapat tersebar secara geografis. Pihak-pihak tersebut adalah penyedia bahan baku, manufaktur, pusat distribusi, pengecer atau pedagang kecil serta transportasi yang membawa bahan baku, intermediate product atau produk jadi ke pihak-pihak yang membutuhkan. (Lambert et al, 2004). Dari definisi - definisi di atas dapat disimpulkan bahwa rantai pasok itu suatu jaringan atau kegiatan kerjasama dalam pengadaan barang maupun jasa yang saling terkait satu sama lain untuk membuat dan menyalurkan barang dan jasa.

\section{Rantai Pasok Usaha Jasa Konstruksi}

Secara umum struktur tipikal rantai pasok konstruksi melibatkan aliran informasi, material dan finansial (Xue et al., 2005). Kontraktor utama (GC - General 
Contractor) merupakan inti dari rantai pasok konstruksi, dengan mitra klien dan konsultan perencana di dalamnya. Sub kontraktor dapat dianggap sebagai supplier bagi kontraktor utama, dan juga mempunyai supplier tersendiri. Di dalam rantai pasok ini teridentifikasi delapan proses bisnis utama dalam rantai pasok konstruksi yang bersifat lintas organisasi, meliputi manajemen proyek, manajemen layanan klien, manajemen hubungan supplier, manajemen permintaan, pemenuhan order, manajemen aliran konstruksi, manajemen lingkungan, dan penelitian dan pengembangan (Xue et al., 2005). Behera et al (2015) menyimpulkan bahwa karakteristik rantai pasok proyek konstruksi dipengaruhi antara lain oleh pengaruh konsumen, fragmentasi, jumlah dan tipe stakeholder, hubungan buyer-supplier, multi organisasi yang bersifat temporer, tipe rantai pasok pembuatan sesuai pesanan (make-to-order), dan peluang kolaborasi, dan pemesanan berulang (cyclical demand). Aloini et al (2012) merangkum karakteristik industri konstruksi yang dipandang akan berpengaruh pada penerapan manajemen rantai pasok pada proyek konstruksi, meliputi antara lain: sistem produksi, pengaruh pelanggan, fragmentasi, stakeholder, hubungan buyer-supplier, konfigurasi temporal, dan inersia perubahan. Untuk memastikan kesuksesan proyek, maka diperlukan sistem manajemen rantai pasok konstruksi yang handal. Manajemen rantai pasok konstruksi dapat didefinisikan sebagai suatu sistem di mana supplier, kontraktor, arsitek dan klien bekerja bersama di bawah koordinasi kontraktor utama untuk memproduksi, mengirim, merakit dan menggunakan informasi, material, peralatan, sumber daya lainnya untuk sebuah proyek konstruksi (Hatmoko \& Scott, 2010). Dalam hal ini, kontraktor utama sebagai koordinator utama mempunyai posisi strategis untuk mengatur semua stakeholder dan sumber daya sepanjang rantai pasok proyek. Untuk memastikan proyek dapat selesai tepat waktu, kontraktor utama harus mengantisipasi dan meminimalkan risiko keterlambatan sepanjang rantai pasok. Model Tipikal rantai pasok konstruksi menurut Xue et al (2005) dapat dilihat pada Gambar 2.

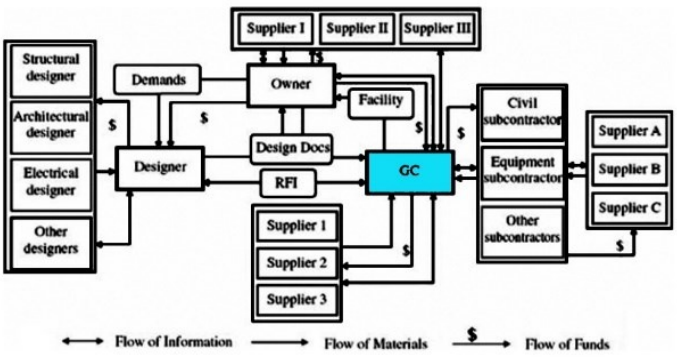

Gambar 2. Model tipikal rantai pasok konstruksi Xue

Tier rantai pasok selanjutnya terdiri atas para pemasok, agen, penyedia jasa spesialis dan/atau pabrikan pendukung pada tier di atasnya. Sistem rantai pasok konstruksi seperti terlihat dalam Gambar 3. (Suraji, 2012)

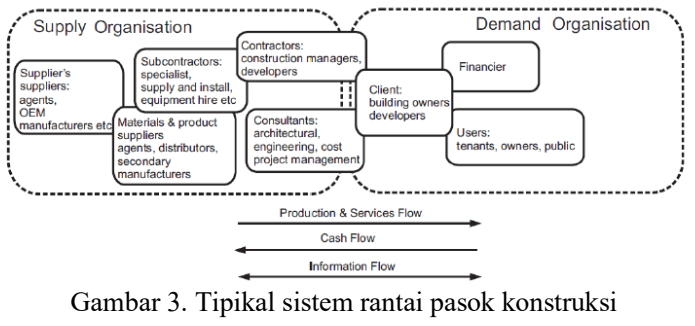

Kategori Rantai Pasok Usaha Jasa Konstruksi

Rantai pasok konstruksi dapat dibagi menjadi 3 kategori berdasarkan lingkupnya, yaitu Rantai Pasok Intra-organizational, Rantai Pasok Interorganizational, dan Rantai Pasok Cross organizational. Rantai Pasok Intra-organizational merupakan sistem paling sederhana karena nilainilainya bisa dikendalikan oleh satu organisasi. Sedangkan sistem yang paling kompleks terdapat pada Rantai Pasok Cross-organizational karena nilainilainya hanya dapat ditetapkan oleh dua atau lebih organisasi. Rantai pasok yang dapat diterapkan pada lingkup proyek yang terbatas adalah Rantai Pasok Intra-organizational sedangkan pada proyek-proyek dengan lingkup yang lebih luas dapat diterapkan Rantai Pasok Inter-organizational. Lalu Rantai Pasok Cross Organizational dapat diterapkan pada kegiatan yang banyak melibatkan pemangku kepentingan konstruksi yang berbeda, contohnya adalah kegiatan pembinaan konstruksi yang dilakukan oleh Kementerian dan Lembaga Pengembangan Jasa Konstruksi.

\section{Struktur Rantai Pasok Usaha Jasa Konstruksi}

Pengertian dari struktur rantai pasok adalah susunan suatu item kegiatan atau jaringan kerjasama pengadaan barang atau jasa yang bekerja sama dan saling terkait satu sama lain untuk membuat dan menyalurkan barang atau jasa. Struktur rantai pasok adalah susunan pengelolaan suatu jaringan bisnis yang saling berhubungan yang terlibat dalam penyediaan akhir paket-paket produk dan layanan yang diperlukan oleh konsumen akhir. (Harland, 1996)

O’Brien (2002) menggambarkan konsep rantai pasok yang biasa diaplikasikan pada jasa konstruksi seperti pada Gambar 4.

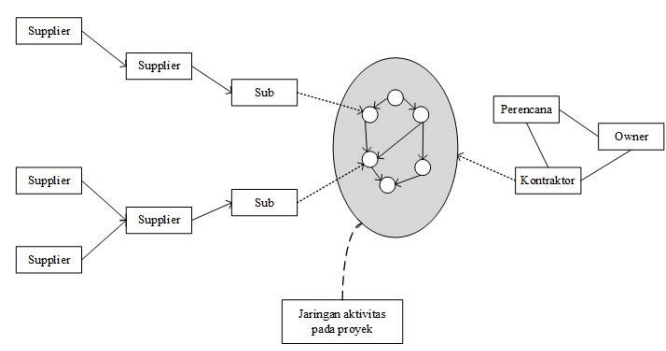

Gambar 4. Konsep Rantai Pasok Konstruksi O’Brien 
Pada Gambar 4 dapat terlihat bahwa kontraktor adalah pihak yang menangani supply chain konstruksi secara praktis. Semua proses baik pengadaan maupun pengolahan ada dalam kendali kontraktor. Hal tersebut selama ini dianggap efektif, mengingat konsumen akhir (owner) dari rantai pasok tersebut tidak terlalu dilibatkan dalam kegiatan tersebut. Sehingga konsumen akhir tidak terlalu mengetahui mengenai permasalahan yang terjadi site project. Optimasi di site project masih sangat mungkin untuk dilaksanakan, hal tersebut dapat berdampak langsung pada penurunan cost dan peningkatan kualitas. Dari beberapa laporan di beberapa negara juga ditemukan hal-hal yang masih dapat dioptimumkan.

Masalah logistik umum di lokasi seperti pengiriman terlambat dan bahan yang salah adalah hasil dari bagaimana rantai pasokan dikelola. (Vrijhoef dan Koskela, 2000). Manajemen rantai pasok yang tidak memadai mempengaruhi biaya, produktivitas, waktu, dan kualitas produk akhir dalam industri konstruksi (Fearne dan Fowler 2006).

\section{Tren Proyek Pekerjaan}

Untuk mengetahui kecenderungan pertumbuhan proyek maka dilakukan analisis tren pertumbuhan proyek dari tahun ke tahun menggunakan metode regresi linear dengan model time series.

Metode ramalan ini disusun berdasarkan pola hubungan data yang relevan di masa lalu. Terdapat tiga kondisi agar metode regresi ini dapat digunakan, yaitu: 1. Informasi data masa lalu lengkap. 2. Informasinya dapat dikuantifikasikan dalam bentuk kata. 3. Dapat diasumsikan bahwa pola hubungan data pada masa lalu dan saat ini akan berkelanjutan dimasa yang akan datang.

Pada metode regresi, terdapat dua variable yaitu variabel yang dicari (dependent variable) dan variabel bebas (independent variable). Besarnya variable yang dicari dipengaruhi oleh variable bebas. Contoh variable yang dicari misalnya ramalan penjualan atau ramalan permintaan suatu produk. Analisa hubungan dalam penyusunan ramalan dapat dibagi menjadi dua macam, yaitu: Analisa cross section atau model sebab akibat (causal model) dan Analisa deret waktu (time series). Analisa cross section merupakan cara peramalan yang menghubungkan pola variable yang diramalkan atau dicari dengan variable-variabel bebas yang mempengaruhi selain variable waktu. Sedangkan analisa deret waktu merupakan peramalan dengan menghubungkan variable yang dicari dan variable waktu sebagai satu-satunya variable yang mepengaruhi variable yang dicari.

Salah satu kelebihan analisa deret waktu dibanding nalisa cross section adalah dapat dipergunakan secara mudah dalam peramalan, meskipun dari segi keberhasilan atau ketepatan lebih baik analisa cross section.

Dalam memilih metode deret waktu, kita perlu mempertimbangkan pola dari data yang diobservasi, apakah pola tersebut dapat ditest atau tidak. Pola yang sederhana dari analisa regresi adalah pola garis lurus yang menunjukkan hubungan antara 2 variabel. Pola tersebut dapat dinyatakan sebagai $\mathrm{Y}=\mathrm{a}+\mathrm{b}$ X Dimana $\mathrm{Y}$ adalah variabel yang diramalkan, $\mathrm{x}$ adalah variabel waktu, serta a dan b adalah parameter atau koefisien regresi. Garis tersebut dinyatakan sebagai berikut:

$$
Y^{\prime}=a+b X
$$

Untuk mendapatkan nilai a dan b maka bisa didapatkan dari rumus berikut:

$$
\begin{aligned}
& a=\frac{\Sigma y-b_{\Sigma} x}{n} \\
& b=\frac{n \sum X Y-\left(\sum X\right)\left(\sum Y\right)}{n \sum X^{2}-\left(\sum X\right)^{2}}
\end{aligned}
$$

Rumus MAPE (Mean Absolute Presetage Error) dan MSE (Mean Square Error) yang terdapat adalah:

$$
\begin{aligned}
& M S E=\frac{\sum_{t=1}^{n}\left(Y_{t}-Y_{t}^{\prime}\right)}{n} \\
& M A P E=\frac{\sum_{t=1}^{n} \frac{\left|Y_{t}-Y_{t}^{\prime}\right|}{Y_{t}}}{n}
\end{aligned}
$$

Dimana :

$$
\begin{aligned}
Y & : \text { Permintaan } \\
Y & : \text { Nilai yang diramalkan } \\
a & : \text { Konstanta (Intercept) } \\
b & : \text { Koefisien regresi (Slope) } \\
t & : \text { Variabel yang mempengaruhi (waktu : } \\
& \text { Tahun, Bulan, Hari) } \\
n & : \text { Jumlah data }
\end{aligned}
$$

\section{METODE PENELITIAN}

Metode penelitian yang digunakan dalam penelitian Analisa Rantai Pasok Material Usaha Jasa Konstruksi di Kabupaten Tasikmalaya secara keseluruhan ditujukan pada Gambar 5.

\section{Persiapan}

Pada tahapan ini kajian terkait rantai pasok usaha jasa konstruksi dari data sekunder serta program kerja mulai disusun. Kemudian hasil dari tahapan ini dituangkan pada laporan pendahuluan. 


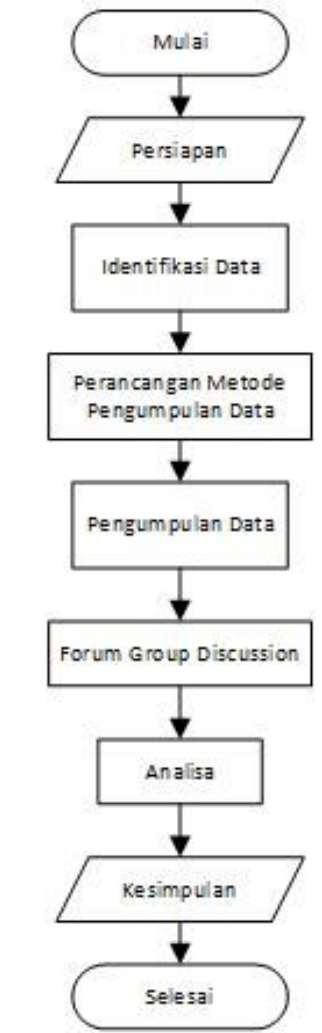

Gambar 5. Flow Chart Penelitian

Identifikasi Data, Perancangan Metoda Pengumpulan Data, Pengumpulan Data dan FGD Identifikasi data adalah identifikasi bahan material yang digunakan dalam jasa konstruksi. Identifikasi bahan/material jasa konstruksi yang mayoritas dipakai dalam pelaksanaan pekerjaan konstruksi dilakukan dengan wawancara dan mendatangi instansi terkait untuk meminta sejumlah dokumentasi data dari institusi yang terlibat dalam usaha jasa konstruksi dan sejumlah instansi lain yang mengelola usaha jasa konstruksi.

Perancangan metoda pengumpulan data dibagi ke dalam dua sub, antara lain:

a) Identifikasi Responden

Teknik yang digunakan dalam memilih responden adalah teknik non-probability sampling yaitu purposive sampling dimana responden yang dipilih hanya pihak-pihak yang terlibat baik secara langsung maupun tidak langsung dengan usaha jasa konstruksi di Kabupaten Tasikmalaya. Purposive sampling dipilih karena dalam penelitian ini memerlukan kriteria khusus agar sampel yang diambil nantinya sesuai dengan tujuan penelitian dan dapat memecahkan permasalahan penelitian serta dapat memberikan nilai yang lebih representatif. Sehingga teknik yang diambil dapat memenuhi tujuan sebenarnya dilakukannya penelitian. Pihak-pihak tersebut antara lain penyedia jasa, pengguna jasa, supplier material, peralatan dan jasa, serta instansi/ pihak terkait. Dengan purposive sampling yang digunakan, sampel yang didapat akan mewakili seluruh populasi dalam penelitian ini.

b) Rancangan survei, wawancara, pengamatan dan penghitungan

Rancangan survei, wawancara disusun dengan mempertimbangkan tujuan survei berkaitan dengan data yang diinginkan, ukuran/skala hasil survei, dan efisiensi pengambilan data terhadap pihak-pihak yang dipilih sebagai responden yaitu yang terlibat baik secara langsung maupun tidak langsung dengan usaha jasa konstruksi di Kabupaten Tasikmalaya. Pihak-pihak tersebut antara lain penyedia jasa, pengguna jasa, supplier material, peralatan dan jasa, serta instansi/ pihak terkait

c) Pengumpulan Data dilakukan dengan cara survei, observasi lapangan serta wawancara dengan pihak-pihak yang terlibat dalam usaha jasa konstruksi di Kabupaten Tasikmalaya.

d) FGD (Focus Group Discussion) dilakukan dengan pihak Dinas Binamarga dan para tenaga ahli. Hal ini dilakukan untuk memvalidasi data yang diperoleh dari lapangan. Tahapan ini kemudian dituangkan pada laporan antara.

\section{Analisis}

Pada tahapan ini, data yang sudah terkumpul kemudian akan di analisa. Untuk analisa model rantai pasok dilakukan dengan cara membandingkan modelmodel yang sudah dikembangkan oleh para ahli dengan kondisi eksisting di lapangan. Kemudian untuk analisa ketersediaan bahan dilakukan dengan pendekatan regresi sebagai alat untuk meramalkan tren pekerjaan, yang kemudian dibandingkan dengan keadaan eksisting sumberdaya yang tersedia. Yang terakhir pola interaksi rantai pasok material usaha jasa konstruksi dilakukan dengan cara observasi kondisi eksisting yang terjadi di lapangan. Hasil analisa ini kemudian diseminarkan sebagai tahapan validasi laporan, selanjutnya disusun dalam bentuk laporan akhir.

\section{ANALISIS}

\section{Ketersediaan Bahan atau Material}

Persediaan/pasokan material/bahan yang sangat tergantung kebijakan nasional dan tingkat konsumsi secara nasional adalah sebagai berikut:

a. Semen

Meningkatnya program Masterplan Percepatan dan Perluasan Pembangunan Ekonomi Indonesia (MP3EI) yang dicanangkan pemerintah sehingga menambah permintaan/konsumsi semen nasional, akan tetapi antara kapasitas produksi dibanding dengan permintaan pasar terdapat selisih yang relatif besar sebagaimana Tabel 1 . 
Tabel 1 Produksi dan Konsumsi Semen Nasional Tahun 2018

\begin{tabular}{|c|c|c|}
\hline $\begin{array}{c}\text { Produksi } \\
\text { (juta Ton) }\end{array}$ & $\begin{array}{c}\text { Konsumsi/Permintaan } \\
\text { (juta Ton) }\end{array}$ & Keterangan \\
\hline 107 & 74,6 & surplus \\
\hline
\end{tabular}

Sumber : Asosiasi Semen Indonesia(ASI)

b. Baja

Sebagaimana konsumsi baja, akibat meningkatnya program Masterplan Percepatan dan Perluasan Pembangunan Ekonomi Indonesia (MP3EI) yang dicanangkan pemerintah sehingga menambah permintaan/ konsumsi baja nasional, akan tetapi antara kapasitas produksi dibanding dengan permintaan pasar terdapat selisih yang relatif besar sebagaimana Tabel 2 .

Tabel 2. Produksi dan Konsumsi Baja Nasional Tahun 2018

\begin{tabular}{|c|c|c|c|}
\hline NO & $\begin{array}{c}\text { Produksi } \\
\text { (juta Ton) }\end{array}$ & $\begin{array}{c}\text { Konsumsi/Permintaan } \\
\text { (juta Ton) }\end{array}$ & Keterangan \\
\hline 1 & 14 & 8 & Surplus \\
\hline \multicolumn{4}{|c}{ Sumber : diolah dari berbagai sumber }
\end{tabular}

c. Aspal

Sama halnya dengan konsumsi semen dan baja, akibat meningkatnya program Masterplan Percepatan dan Perluasan Pembangunan Ekonomi Indonesia (MP3EI) yang dicanangkan pemerintah sehingga menambah permintaan/konsumsi aspal nasional, akan tetapi antara kapasitas produksi dibanding dengan permintaan pasar terdapat selisih yang relatif besar sebagaimana Tabel3.

Tabel 3. Produksi dan Konsumsi Aspal Nasional Tahun 2018

\begin{tabular}{|c|c|c|}
\hline $\begin{array}{c}\text { Produksi } \\
\text { (juta Ton) }\end{array}$ & $\begin{array}{c}\text { Konsumsi/Permintaan } \\
\text { (juta Ton) }\end{array}$ & Keterangan \\
\hline 1800 & 344 & Surplus \\
\hline
\end{tabular}

Sumber : diolah dari berbagai sumber

Untuk bahan/material yang berkait dengan kebijakan nasional jumlah ketersediaan/pasokan dipastikan oleh negara tingkat ketersediaannya dan bahkan ada beberapa komoditas yang ditentukan harganya sehingga bahan/material tersebut dijamin tidak akan terjadi kelangkaan.

d. Material tambang

Disamping bahan/material diatas terdapat bahan/material yang sangat tergantung kebijakan pemerintah daerah dan input yang signifikan untuk pelaksanaan pekerjaan konstruksi. Bahan/material tersebut berasal dari alam yang diperoleh sebagai bahan galian/tambang, yang berupa bahan baku (misal batu, pasir) dan bahan olahan(misal agragat kasar dan agragat halus). Berat isi atau berat jenis yang berdasarkan hasil uji laboratorium sebagaimana Tabel 4.
Tabel 4. Berat Isi Agregat

\begin{tabular}{|c|l|c|c|c|c|c|}
\hline \multirow{2}{*}{ No. } & \multirow{2}{*}{$\begin{array}{c}\text { Nama } \\
\text { Bahan }\end{array}$} & \multicolumn{2}{|c|}{$\begin{array}{c}\text { Berat Isi Padat } \\
(\mathbf{B i P}) \\
\left(\mathbf{T} / \mathbf{m}^{\mathbf{2}}\right)\end{array}$} & \multicolumn{2}{c|}{$\begin{array}{c}\text { Berat Isi Lepas } \\
(\mathbf{B i L}) \\
\left(\mathbf{T} / \mathbf{m}^{\mathbf{2}}\right)\end{array}$} & \multirow{2}{*}{$\begin{array}{c}\text { Penyerapan } \\
(\%)\end{array}$} \\
\cline { 3 - 6 } & & Min & Maks & Min & Maks & \\
\hline \multirow{2}{*}{1} & $\begin{array}{l}\text { Agregat } \\
\text { kasar }\end{array}$ & 1,360 & 1,450 & 1,236 & 1,283 & $1,94-2,02$ \\
\cline { 2 - 6 } 2 & 1,320 & 1,380 & 1,200 & 1,221 & $2,50-2,65$ \\
\hline \multirow{2}{*}{2} & $\begin{array}{l}\text { Agregat } \\
\text { halus }\end{array}$ & 1,380 & 1,540 & 1,255 & 1,363 & $1,65-1,93$ \\
\hline
\end{tabular}

Sumber : Permen PU No. 28/PRT/M/2016

Bahan/material untuk keperluan pelaksanaan pembangunan infrastruktur di wilayah Priangan Timur bahkan sampai ke Jakarta mayoritas berasal dari Kabupaten dan Kota Tasikmalaya, Berdasarkan hasil pengamatan, ada ratusan bahkan ribuan kubik pasir, batu belah dan agragat setiap harinya diproduksi oleh quarry atau perusahaan pemecah batu.

Tabel 5. Berat Isi Jenis-jenis Agregat

\begin{tabular}{|c|c|c|c|c|c|}
\hline \multirow[t]{2}{*}{ No. } & \multirow[t]{2}{*}{ Nama Bahan } & \multicolumn{2}{|c|}{\begin{tabular}{|c|} 
Berat Isi Padat \\
(BiP) \\
$\left(\mathrm{T} / \mathrm{m}^{3}\right)$
\end{tabular}} & \multicolumn{2}{|c|}{$\begin{array}{c}\text { Berat Isi Lepas } \\
\text { (BiL) } \\
\left(\mathrm{T} / \mathrm{m}^{3}\right)\end{array}$} \\
\hline & & Min & Maks & Min & Maks \\
\hline 1 & Water bound Macadam (5/7), Agregat Kls-C & 1,740 & 1,920 & 1,582 & 1,699 \\
\hline 2 & Batu belah (gunung/kali) & 1,200 & 1,600 & 0,914 & 0,960 \\
\hline$\frac{2}{3}$ & Batu kali & $\frac{1,200}{1,200}$ & 1,700 & 0,960 & 0,971 \\
\hline 4 & Abu batu hasil pemecah batu & 1,400 & 1,900 & 1,261 & 1,624 \\
\hline 5 & Chip (lolos $3 / 4^{\prime}$ tertahan No.4) & 1,220 & 1,300 & 1,109 & 1,150 \\
\hline 6 & Chip ( lolos No. 4 tertahan No.8) & 1,430 & 1,500 & 1,300 & 1,327 \\
\hline 7 & Gravel / Sirtu dipecah dgn pemecah batu & 1,620 & 1,950 & 1,373 & 1,473 \\
\hline 8 & Agregat halus, hasil pemecah batu & 1,380 & 1,540 & 1,254 & 1,363 \\
\hline 9 & $\begin{array}{l}\text { Agregat kasar, hasil pemecah } \\
\text { batu/split/screen }\end{array}$ & 1,320 & 1,450 & 1,200 & 1,283 \\
\hline 10 & Agregat Kelas A, Kelas S & 1,740 & 1,850 & 1,303 & 1,582 \\
\hline 11 & Agregat Kelas B & 1,760 & 1,880 & 1,324 & 1,600 \\
\hline 12 & Sirtu & 1,620 & 2,050 & 1,444 & 1,473 \\
\hline 13 & Split, screen hasil pemecah batu & 1,400 & 1,750 & 1,232 & 1,273 \\
\hline 15 & Pasir pasang, kasar & 1,380 & 1,540 & 1,243 & 1,316 \\
\hline 16 & Pasir urug & 1,300 & 1,600 & 1,040 & 1,151 \\
\hline 17 & Agregat ringan & 1,300 & 1,500 & 0,600 & 0,750 \\
\hline 18 & Tanah biasa & 1,350 & 1,650 & 1,000 & 1,200 \\
\hline 19 & Tanah gambut & 0,850 & 1,150 & 0,600 & 0,850 \\
\hline
\end{tabular}

Sumber Permen PU No. 28/PRT/M/2016

Beberapa quarry menerima supply bahan mentah untuk diproduksi jadi agregat berasal dari usaha tambangnya sendiri. Beberapa quarry yang lain memproduksi agregat memperoleh bahan baku batu belah dari usaha tambang perusahaan lain.

Hasil survei lapangan terhadap 23 quarry yang tersebar di wilayah Kabupaten dan Kota Tasikmalaya, diperoleh data bahwa setiap quarry memiliki kapasitas dan spesialisasi yang berbeda-beda. Dari jumlah tersebut ada 6 quarry mengolah bahan baku dari hasil tambangnya sendiri, 17 quarry yang mengambil bahan baku dari usaha tambang lain. Berdasarkan survei lapangan diperoleh data 6 quarry yang masih memiliki gunung yang belum dieksplorasi. Data hasil survei lapangan sebagaimana pada Tabel 6 .

Tabel 6. Produksi Tahunan Quarry

\begin{tabular}{|l|l|c|}
\hline No & Jenis Bahan & Material Terpakai $\left(\mathbf{M}^{\mathbf{3}} /\right.$ tahun) \\
\hline 1. & Batu & 144.900 \\
\hline 2. & Pasir & 284.550 \\
\hline 3. & Screen & 148.805 \\
\hline 4. & Split $(1 / 2 ; 2 / 3,3 / 5)$ & 690.030 \\
\hline 5. & Abu Batu & 156.450 \\
\hline
\end{tabular}

Sumber : Diolah dari survey th. 2018 
Adapun dari hasil observasi diketahui produksi tahunan bahan galian menghabiskan material seperti terlihat pada Tabel 7 .

Tabel 7. Perkiraan Jumlah Paket Pekerjaan

\begin{tabular}{|c|c|c|c|}
\hline \multirow[b]{2}{*}{ Tahun } & \multicolumn{3}{|c|}{$\begin{array}{c}\text { Prakiraan Besaran } \\
\text { Paket Pekerjaan (dalam ribuan rupiah) }\end{array}$} \\
\hline & $\begin{array}{c}\text { Jalan \& } \\
\text { Jembatan }\end{array}$ & $\begin{array}{c}\text { Sumber daya } \\
\text { Air (SDA) }\end{array}$ & $\begin{array}{c}\text { Kawasan } \\
\text { Strategis Cpt } \\
\text { Tumbuh } \\
\end{array}$ \\
\hline 2019 & 28.853 .645 & 47.613 .769 .012 & 74.279 .547 .997 \\
\hline 2020 & 231.663 .233 & 50.941 .063 .423 & 88.685 .872 .397 \\
\hline 2021 & 234.472 .821 & 54.268 .357 .834 & 103.092 .196 .797 \\
\hline 2022 & 237.282 .409 & 57.595 .652 .245 & 117.498 .521 .197 \\
\hline 2023 & 240.091 .997 & 60.922 .946 .656 & 131.904 .845 .597 \\
\hline 2024 & 242.901 .585 & 64.250 .241 .067 & 146.311 .169 .997 \\
\hline 2025 & 245.711 .173 & 67.577 .535 .478 & 160.717 .494 .397 \\
\hline 2026 & 248.520 .761 & 70.904 .829 .889 & 175.123 .818 .797 \\
\hline 2027 & 251.330 .349 & 74.232 .124 .300 & 189.530 .143 .197 \\
\hline 2028 & 254.139 .937 & 77.559 .418 .711 & 203.936 .467 .597 \\
\hline 2029 & 256.949 .525 & 80.886 .713 .122 & 218.342 .791 .997 \\
\hline 2030 & 259.759 .113 & 84.214 .007 .533 & 232.749 .116 .397 \\
\hline 2031 & 262.568 .701 & 87.541 .301 .944 & 247.155 .440 .797 \\
\hline 2032 & 265.378 .289 & 90.868 .596 .355 & 261.561 .765 .197 \\
\hline 2033 & 268.187 .877 & 94.195 .890 .766 & 275.968 .089 .597 \\
\hline
\end{tabular}

e. Tren Pertumbuhan Proyek

Dengan menggunakan analisa regresi linear dengan model time series dapat digambarkan pertumbuhan proyek sebagaimana ditunjukkan pad Tabel 8.

f. Utilisasi Proyek Pekerjaan

Utilisasi material untuk proyek pekerjaan akan diklasifikasi berdasar jenis pekerjaan. Berikut utilisasi material untuk setiap proyek pekerjaan:

Tabel 8. Potensi tambang terkira galian $\mathrm{C}$

\begin{tabular}{|c|c|c|c|c|}
\hline \multirow{2}{*}{ No } & \multirow{2}{*}{$\begin{array}{c}\text { Nama } \\
\text { Perusahaan }\end{array}$} & \multicolumn{3}{|c|}{$\begin{array}{l}\text { Potensi Terkira Tambang/Galian C } \\
\left(\mathrm{m}^{3}\right)\end{array}$} \\
\hline & & Batu & Pasir & $\begin{array}{c}\text { B.Baku/ } \\
\text { Berangkal }\end{array}$ \\
\hline 1 & CV. Kerta Mekar & 180.850 & 126.800 & 793.550 \\
\hline 2 & CV. Padmas & 175.000 & 126.100 & 538.000 \\
\hline 3 & $\begin{array}{l}\text { PT. Barkah } \\
\text { Borneo } \\
\text { Membangun }\end{array}$ & & & \\
\hline 4 & PT. YHN & 120.920 & 210.920 & 350.000 \\
\hline 5 & PD. Gayam 2 & & & \\
\hline 6 & CV. Anak Sejati & 324.000 & 1.426 .500 & 257.000 \\
\hline 7 & CV. Sribayu & & 163.400 & \\
\hline 8 & PD. Gayam 3 & & & \\
\hline 9 & PD. Gayam 1 & & & \\
\hline 10 & PD. Gayam 4 & & & \\
\hline 11 & SNA 1 & & & \\
\hline 12 & SNA 2 & & & \\
\hline 13 & SNA 3 & & & \\
\hline 14 & SNA 4 & & & \\
\hline 15 & $\begin{array}{l}\text { PT. Parawasta } \\
\text { Sugih Jaya }\end{array}$ & & & 821.083 \\
\hline 16 & PT. Manandi & 236.000 & & 426.000 \\
\hline 17 & RDS & & & \\
\hline 18 & CV. GM & & & \\
\hline 19 & PT.BMI & & & \\
\hline 20 & $\begin{array}{l}\text { CV. Nusa Karya } \\
\text { Prima }\end{array}$ & & & \\
\hline 21 & CV. Abadi Jaya & & & \\
\hline 22 & PT. Gunadharma & & & 634.000 \\
\hline 23 & CV Putra Mandiri & & 1.128 .625 & \\
\hline 24 & $\begin{array}{l}\text { PT. Trie Mukty } \\
\text { Pertama Putra }\end{array}$ & 1.154 .000 & & 1.456 .000 \\
\hline & JUMLAH & 2.189 .850 & 3.182 .345 & 5.275 .633 \\
\hline
\end{tabular}

Sumber : Diolah dari survey th. 2018

\section{Proyek Pekerjaan Jalan}

Pekerjaan jalan merupakan pekerjaan dengan total nilai yang paling besar, jenis pekerjaan jalan terdiri dari pembangunan jalan, peningkatan jalan dan pemeliharaan jalan. Untuk menghitung kebutuhan bahan/material disesuaikan dengan jenis konstruksinya. Dalam kajian ini jenis konstruksi perkerasan jalan yang dipilih adalah memakai hotmix karena merupakan kebijakan kepala daerah. Berdasarkan analisis harga satuan pekerjaan dan survey lapangan diperoleh data koefisien bahan seperti dapat dilihat pada Tabel 9.

Tabel 9. Koefisien Bahan Untuk Pekerjaan Jalan
\begin{tabular}{|l|r|}
\hline Koefisien Pasir & 0,0405 \\
\hline Koefisien Batu & 0,5350 \\
\hline Koefisien Split & 0,3645 \\
\hline
\end{tabular}

Dari Tabel koefisien tersebut kemudian menggunakan perhitungan:

Kebutuhan Pasir

$=\left(\frac{\text { Seluruh Biaya proyek }-20 \% \text { Biaya Proyek }}{\text { Biaya per } 3}\right) \times$ Koefisien Pasir

Kebutuhan Batu

$=\left(\frac{\text { Seluruh Biaya proyek }-20 \% \text { Biaya Proyek }}{\text { Biaya per } 33}\right) \times$ Koefisien Batu

Kebutuhan Abu Batu

$=\left(\frac{\text { Seluruh Biaya proyek }-20 \% \text { Biaya Proyek }}{\text { Biaya per } m^{3}}\right) \times$ Koefisien Abu Batu

Maka didapat kebutuhan material untuk lima belas tahun kedepan seperti terlihat pada Tabel 10.

\begin{tabular}{|c|c|c|c|c|}
\hline \multirow[b]{2}{*}{$\begin{array}{l}\text { Tah } \\
\text { un }\end{array}$} & \multicolumn{4}{|c|}{ Kebutuhan Sumber Daya Alam } \\
\hline & $\begin{array}{c}\text { Pasir } \\
\left(\mathbf{M}^{3}\right)\end{array}$ & $\begin{array}{l}\text { Batu } \\
\left(\mathbf{M}^{3}\right)\end{array}$ & $\begin{array}{c}\text { Split/Agre } \\
\text { gat }\left(M^{3}\right)\end{array}$ & $\begin{array}{l}\text { Total } \\
\left(\mathbf{M}^{3}\right)\end{array}$ \\
\hline 2019 & $13.874,63$ & $183.282,13$ & $124.871,66$ & $322.028,41$ \\
\hline 2020 & $14.108,05$ & $186.365,54$ & $126.972,41$ & $327.446,00$ \\
\hline 2021 & $14.341,46$ & $189.448,96$ & $129.073,17$ & $332.863,59$ \\
\hline 2022 & $14.574,88$ & $192.532,37$ & $131.173,92$ & $338.281,17$ \\
\hline 2023 & $14.808,30$ & $195.615,78$ & $133.274,68$ & $343.698,76$ \\
\hline 2024 & $15.041,71$ & $198.699,20$ & $135.375,43$ & $349.116,35$ \\
\hline 2025 & $15.275,13$ & $201.782,61$ & $137.476,19$ & $354.533,93$ \\
\hline 2026 & $15.508,55$ & $204.866,03$ & $139.576,95$ & $359.951,52$ \\
\hline 2027 & $15.741,97$ & $207.949,44$ & $141.677,70$ & $365.369,11$ \\
\hline 2028 & $15.975,38$ & $211.032,85$ & $143.778,46$ & $370.786,69$ \\
\hline 2029 & $16.208,80$ & $214.116,27$ & $145.879,21$ & $376.204,28$ \\
\hline 2030 & $16.442,22$ & $217.199,68$ & $147.979,97$ & $381.621,87$ \\
\hline 2031 & $16.675,64$ & $220.283,09$ & $150.080,72$ & $387.039,45$ \\
\hline 2032 & $16.909,05$ & $223.366,51$ & $152.181,48$ & $392.457,04$ \\
\hline 2033 & $17.142,47$ & $226.449,92$ & $154.282,24$ & $397.874,63$ \\
\hline
\end{tabular}

\section{Proyek Pekerjaan Jembatan}

Jenis pekerjaan bangunan gedung terdiri dari pekerjaan drainase, pekerjaan tanah, pekerjaan struktur. Untuk menghitung kebutuhan bahan/ material disesuaikan dengan jenis konstruksinya, dalam kajian ini jenis jembatan yang menjadi fokus kajian adalah jembatan dengan konstruksi menggunakan beton prategang dengan drainase pasangan batu. Perhitungan kebutuhan sumber daya alam dalam pembangunan jembatan dihitung berdasarkan analis harga satuan pekerjaan dan survey lapangan dari RAB penyedia jasa yang melaksanakan 
pekerjaan, diperoleh data koefisien bahan seperti pada Tabel 11.

Tabel 11. Koefisien Kebutuhan Bahan Jembatan

\begin{tabular}{|c|c|c|c|}
\hline \multirow{2}{*}{ Nama Pekerjaan } & \multicolumn{3}{|c|}{ Koefisien Kebutuhan bahan/material } \\
\cline { 2 - 4 } & ${\text { Pasir } \mathrm{m}^{3}}^{3}$ & Split $^{3}$ & Batu $^{3}$ \\
\hline Pekerjaan drainase & 0,0003 & - & 0,0017 \\
\hline Pekerjaan struktur & 0,2269 & 0,3119 & 0,0120 \\
\hline
\end{tabular}

Dengan harga beton tepasang setiap $1 \mathrm{~m}^{3}$ beton adalah Rp. 2.357.000,- dan Pasangan Batu setiap 1 m3 Rp. 650.000,-. Dari data-data tersebut, maka dapat dihitung Kebutuhan bahan/material dapat dihitung dengan rumus sebagai berikut:

Kebutuhan Pasir (drainase)

$=\left(\frac{\text { Seluruh Biaya proyek }-20 \% \text { Biaya Proyek }}{2.357 .000,-}\right) \times$ koefisien pasir

Kebutuhan Pasir(struktur)

$=\left(\frac{\text { Seluruh Biaya proyek }-20 \% \text { Biaya Proyek }}{2.357 .000,-}\right) x$ koefisien pasir

Kebutuhan Split

$=\left(\frac{\text { Seluruh Biaya proyek-20\% Biaya Proyek }}{2.357 .000,-}\right) x$ koefisien split

Kebutuhan Batu(drainase)

$=\left(\frac{\text { Seluruh Biaya proyek-20\% Biaya Proyek }}{650.000-}\right) x$ koefisien batu

Kebutuhan Batu(Struktur)

$=\left(\frac{\text { Seluruh Biaya proyek-20\% Biaya Proyek }}{650.000,-}\right) x$ koefisien batu

maka didapat kebutuhan material untuk lima belas tahun kedepan seperti terlihat pada Tabel 12.

Tabel 12. Utilisasi bahan untuk pekerjaan Jembatan

\begin{tabular}{|c|c|c|c|c|c|}
\hline \multirow{2}{*}{ No } & \multirow{2}{*}{ Tahun } & \multicolumn{3}{|c|}{ Kebutuhan Sumber Daya Alam } \\
\cline { 3 - 6 } & & $\begin{array}{c}\text { Pasir } \\
\mathbf{( M}^{\mathbf{3}} \mathbf{)}\end{array}$ & $\begin{array}{c}\text { Batu } \\
\mathbf{( M}^{\mathbf{3}} \mathbf{)}\end{array}$ & $\begin{array}{c}\text { Split/Agr } \\
\text { egat }\end{array} \mathbf{M}^{\mathbf{3}} \mathbf{)}$ & $\begin{array}{c}\text { Total } \\
\mathbf{( M}^{\mathbf{3}} \mathbf{)}\end{array}$ \\
\hline 1 & 2019 & 713,75 & 287,95 & 727,95 & $1.729,65$ \\
\hline 2 & 2020 & 713,97 & 288,04 & 728,18 & $1.730,20$ \\
\hline 3 & 2021 & 714,20 & 288,13 & 728,41 & $1.730,74$ \\
\hline 4 & 2022 & 714,42 & 288,23 & 728,64 & $1.731,28$ \\
\hline 5 & 2023 & 714,64 & 288,32 & 728,86 & $1.731,82$ \\
\hline 6 & 2024 & 714,87 & 288,41 & 729,09 & $1.732,37$ \\
\hline 7 & 2025 & 715,09 & 288,50 & 729,32 & $1.732,91$ \\
\hline 8 & 2026 & 715,32 & 288,59 & 729,55 & $1.733,45$ \\
\hline 9 & 2027 & 715,54 & 288,68 & 729,78 & $1.733,99$ \\
\hline 10 & 2028 & 715,76 & 288,77 & 730,01 & $1.734,54$ \\
\hline 11 & 2029 & 715,99 & 288,86 & 730,23 & $1.735,08$ \\
\hline 12 & 2030 & 716,21 & 288,95 & 730,46 & $1.735,62$ \\
\hline 13 & 2031 & 716,43 & 289,04 & 730,69 & $1.736,16$ \\
\hline 14 & 2032 & 716,66 & 289,13 & 730,92 & $1.736,71$ \\
\hline 15 & 2033 & 716,88 & 289,22 & 731,15 & $1.737,25$ \\
\hline \multicolumn{5}{|c|}{ Sumber : Diolah dari survey th. 2018 } \\
\hline
\end{tabular}

Pekerjaan Sumber Daya Air (SDA) dan TPT

Jenis pekerjaan sumber daya air terdiri dari pekerjaan tanah, pekerjaan fondasi, pekerjaan beton, pekerjaan pasangan. Untuk menghitung kebutuhan bahan/ material disesuaikan dengan jenis konstruksinya, dalam kajian ini jenis pekerjaan yang menjadi fokus adalah pekerjaan pasangan dan sebagai mayor item dari pekerjaan pasangan tersebut adalah pasangan batu, sehingga untuk analisa kebutuhan bahan/ material pekerjaan tpt disatukan. Berdasarkan analis harga satuan pekerjaan dan survei lapangan diperoleh data koefisien bahan yang ditunjukkan pada Tabel 13 .

Tabel 13. Koefisien Bahan Pekerjaan TPT

\begin{tabular}{|c|c|c|}
\hline \multirow{2}{*}{ Nama Pekerjaan } & \multicolumn{2}{|c|}{ Koefisien } \\
\cline { 2 - 3 } & Pasir & Split \\
\hline Pekerjaan Pasangan Batu & 0,2338 & 0,6575 \\
\hline
\end{tabular}

Setiap $1 \mathrm{~m}^{3}$ Pekerjaan Pasangan biaya yang dikeluarkan yaitu Rp. 650.000.- Berdasarkan nilai tersebut dapat dicari bahan/material yang dibutuhkan. dengan formula sebagai berikut:

Kebutuhan Pasir

$=\left(\frac{\text { Seluruh Biaya proyek }-20 \% \text { Biaya Proyek }}{\text { Biaya per } m^{2}}\right) \times$ Koefisien Pasir

Kebutuhan Split/Agregat

$=\left(\frac{\text { Seluruh Biaya proyek }-20 \% \text { Biaya Proyek }}{\text { Biaya per } m^{2}}\right) x$ Koefisien Split

Maka didapatkan hasil kebutuhan bahan/material dari sumber daya alam/bahan tambang seperti pada Tabel 14.

\begin{tabular}{|c|c|c|c|c|}
\hline \multirow{2}{*}{ No } & \multirow{2}{*}{ Tahun } & \multicolumn{3}{|c|}{ Kebutuhan Sumber Daya Alam } \\
\hline & & Pasir $\left(\mathbf{M}^{3}\right)$ & Batu $\left(M^{3}\right)$ & Total $\left(\mathbf{M}^{3}\right)$ \\
\hline 1 & 2019 & $23.001,68$ & $62.731,85$ & $85.733,52$ \\
\hline 2 & 2020 & $25.751,91$ & $70.232,48$ & $95.984,38$ \\
\hline 3 & 2021 & $28.502,14$ & $77.733,10$ & $106.235,24$ \\
\hline 4 & 2022 & $31.252,37$ & $85.233,73$ & $116.486,10$ \\
\hline 5 & 2023 & $34.002,60$ & $92.734,36$ & $126.736,96$ \\
\hline 6 & 2024 & $36.752,83$ & $100.234,99$ & $136.987,82$ \\
\hline 7 & 2025 & $39.503,06$ & $107.735,62$ & $147.238,68$ \\
\hline 8 & 2026 & $42.253,29$ & $115.236,25$ & $157.489,54$ \\
\hline 9 & 2027 & $45.003,52$ & $122.736,88$ & $167.740,40$ \\
\hline 10 & 2028 & $47.753,75$ & $130.237,51$ & $177.991,26$ \\
\hline 11 & 2029 & $50.503,98$ & $137.738,13$ & $188.242,12$ \\
\hline 12 & 2030 & $53.254,21$ & $145.238,76$ & $198.492,98$ \\
\hline 13 & 2031 & $56.004,44$ & $152.739,39$ & $208.743,84$ \\
\hline 14 & 2032 & $58.754,67$ & $160.240,02$ & $218.994,70$ \\
\hline 15 & 2033 & $23.001,68$ & $62.731,85$ & $85.733,52$ \\
\hline
\end{tabular}

\section{Pekerjaan Bangunan Gedung}

Jenis pekerjaan bangunan gedung terdiri dari pekerjaan tanah, pekerjaan fondasi, pekerjaan beton, pekerjaan besi/aluminium, pekerjaan dinding pasangan, pekerjaan penutup lantai dan penutup dinding, pekerjaan plafon, pekerjaan penutup atap, dan pekerjaan kayu. Untuk menghitung kebutuhan bahan/material disesuaikan dengan jenis konstruksinya, dalam kajian ini jenis bangunan yang dipilih adalah bangunan tidak sederhana. Berdasarkan analis harga satuan pekerjaan dan survei lapangan diperoleh data koefisien bahan seperti terlihat pada Tabel 14.

Tabel 15. Koefisien Bahan Bangunan Gedung

\begin{tabular}{|l|c|c|c|}
\hline \multirow{2}{*}{ Nama Pekerjaan } & \multicolumn{3}{|c|}{ Koefisien } \\
\cline { 2 - 4 } & Pasir & $\begin{array}{c}\text { Split/ } \\
\text { Agregat }\end{array}$ & $\begin{array}{c}\text { Batu } \\
\text { Belah }\end{array}$ \\
\hline Pekerjaan Struktur & 0,239 & 0,186 & 0,220 \\
\hline Pekerjaan Arsitektur & 0,152 & 0,274 & - \\
\hline $\begin{array}{l}\text { Pekerjaan Sarana dan } \\
\text { Prasarana }\end{array}$ & 0,001 & 0,005 & 0,008 \\
\hline Total & $\mathbf{0 , 3 9 2}$ & $\mathbf{0 , 2 2 7}$ & $\mathbf{0 , 4 6 4}$ \\
\hline
\end{tabular}


Setiap $\mathrm{m}^{2}$ bangunan tidak sederhana sesuai dengan standar harga gedung negara yaitu Rp. 4.676.000. Berdasarkan nilai bangunan diatas dapat dicari bahan/material yang dibutuhkan dengan formula sebagai berikut:

Kebutuhan Pasir

$=\left(\frac{\text { Seluruh Biaya proyek }-20 \% \text { Biaya Proyek }}{\text { Biaya per } m^{2}}\right) \times$ Koefisien Pasir

Kebutuhan Split/Agregat

$=\left(\frac{\text { Seluruh Biaya proyek-20\% Biaya Proyek }}{\text { Biaya per } m^{2}}\right) \times$ Koefisien Pasir

Kebutuhan Batu Belah

$=\left(\frac{\text { Seluruh Biaya proyek }-20 \% \text { Biaya Proyek }}{\text { Biaya per } m^{2}}\right) \times$ Koefisien Pasir

Maka didapatkan hasil kebutuhan bahan/material dari sumber daya alam/bahan tambang seperti pada Tabel 16.

Tabel 16. Utilisasi bahan untuk pekerjaan Bangunan Gedung

\begin{tabular}{|c|c|c|c|c|c|}
\hline \multirow{2}{*}{ No } & \multirow{2}{*}{ Tahun } & \multicolumn{5}{|c|}{ Kebutuhan Sumber Daya Alam } \\
\cline { 3 - 6 } & & Pasir $\left(\mathbf{M}^{\mathbf{3}}\right)$ & $\begin{array}{c}\text { Batu } \\
\left(\mathbf{M}^{\mathbf{3}}\right)\end{array}$ & $\begin{array}{c}\text { Abu Batu } \\
\left(\mathbf{M}^{\mathbf{3}}\right)\end{array}$ & Total $\left(\mathbf{M}^{\mathbf{3}} \mathbf{)}\right.$ \\
\hline 1 & 2019 & $3.119,34$ & $2.886,58$ & $5.902,30$ & $11.908,22$ \\
\hline 2 & 2020 & $3.724,33$ & $3.446,43$ & $7.047,03$ & $14.217,79$ \\
\hline 3 & 2021 & $4.329,32$ & $4.006,27$ & $8.191,77$ & $16.527,36$ \\
\hline 4 & 2022 & $4.934,31$ & $4.566,12$ & $9.336,51$ & $18.836,93$ \\
\hline 5 & 2023 & $5.539,30$ & $5.125,96$ & $10.481,24$ & $21.146,50$ \\
\hline 6 & 2024 & $6.144,28$ & $5.685,81$ & $11.625,98$ & $23.456,07$ \\
\hline 7 & 2025 & $6.749,27$ & $6.245,65$ & $12.770,71$ & $25.765,64$ \\
\hline 8 & 2026 & $7.354,26$ & $6.805,50$ & $13.915,45$ & $28.075,20$ \\
\hline 9 & 2027 & $7.959,25$ & $7.365,34$ & $15.060,18$ & $30.384,77$ \\
\hline 10 & 2028 & $8.564,24$ & $7.925,19$ & $16.204,92$ & $32.694,34$ \\
\hline 11 & 2029 & $9.169,23$ & $8.485,03$ & $17.349,65$ & $35.003,91$ \\
\hline 12 & 2030 & $9.774,21$ & $9.044,88$ & $18.494,39$ & $37.313,48$ \\
\hline 13 & 2031 & $10.379,20$ & $9.604,72$ & $19.639,12$ & $39.623,05$ \\
\hline 14 & 2032 & $10.984,19$ & $10.164,5$ & $20.783,86$ & $41.932,62$ \\
\hline 15 & 2033 & $11.589,18$ & $10.724,4$ & $21.928,60$ & $44.242,19$ \\
\hline
\end{tabular}

\section{Prakiraan Pasokan Vs Permintaan}

Untuk merencanakan pengendalian rantai pasok bahan/material maka perlu diketahui gambaran perkiraan keseimbangan pasokan dengan permintaan barang/material. Bahana/material yang menjadi fokus kajian ini adalah bahan/material quarry (agregat) dengan pertimbangan lingkup pengendaliannya ada di Pemerintah Daerah, ketersediaannya terbatas, merupakan bahan baku utama untuk pekerjaan infrastruktur, memiliki nilai industri yang signifikan, dan fluktuasi harga sangat rentan terhadap keseimbangan pasokan dan permintaan. Untuk mengetahui keseimbangan tersebut diperkirakan perkembangan kebutuhan selama 15 tahun ke depan dimulai dari tahun 2019 serta ketersediaan/cadangan quarry yang tersedia, maka tiap-tiap jenis bahan/material akan diagregatkan lagi berdasarkan asal mulanya sebelum diolah, jadi hanya akan ada satu kebutuhan yaitu bahan baku untuk agregat yang nantinya diolah di perusahaan pemecah batu/stone crusher. Ketersediaan cadangan quarry berlokasi di Kota dan Kabupaten Tasikmalaya dan hasil olahan pada quarry didistribusikan selain ke Kota dan Kabupaten Tasikmalaya juga ke luar Daerah lainnya, berdasarkan hasil survei proporsi distribusi bahan/material ke kota dan Kabupaten Tasikmalaya dan Keluar daerah dapat digambarkan sebagaimana Tabel 17.
Tabel 17. Proporsi Tujuan distribusi quarry

\begin{tabular}{|c|c|c|}
\hline \multicolumn{3}{|c|}{ Tujuan Distribusi Quarry Asal Tasikmalaya } \\
\hline $\begin{array}{c}\text { Kabupaten } \\
\text { Tasikmalaya }\end{array}$ & $\begin{array}{c}\text { Kota } \\
\text { Tasikmalaya }\end{array}$ & $\begin{array}{c}\text { Luar Kabupaten/Kota } \\
\text { Tasikmalaya }\end{array}$ \\
\hline 0,49 & 0,15 & 0,37 \\
\hline
\end{tabular}

Prakiraan kebutuhan dan ketersediaan material atau material alam untuk keperluan Kabupaten Tasikmalaya dapat digambarkan pada Tabel 18 .

Berdasarkan perhitungan pada Tabel 18, disimpulkan bahwa untuk kebutuhan pembangunan infrastruktur yang ada di Kabupaten Tasikmalaya, pasokan agregat/cadangan tambang yang terkira sekarang dapat diprakirakan/di-forecasting sampai 15 tahun kedepan masih aman.

Prakiraan kebutuhan dan ketersediaan material/material alam untuk keperluan Kabupaten/Kota Tasikmalaya dan Daerah lainnya dapat digambarkan pada tabel 18 .

Tabel 18. Prakiraan/forecasting Pasokan dan Kebutuhan Quarry di Kab. Tasikmalaya

\begin{tabular}{|c|c|c|c|}
\hline No & Tahun & $\begin{array}{c}\text { Pasokan/Cadangan } \\
\text { Quarry } \mathbf{( M}^{\mathbf{3}} \mathbf{)}\end{array}$ & $\begin{array}{c}\text { Permintaan } \\
\mathbf{( M}^{\mathbf{3}} \mathbf{)}\end{array}$ \\
\hline 1 & 2019 & $9.730 .828,00$ & $473.911,00$ \\
\hline 2 & 2020 & $9.256 .917,00$ & $494.136,83$ \\
\hline 3 & 2021 & $8.762 .780,17$ & $514.362,65$ \\
\hline 4 & 2022 & $8.248 .417,51$ & $534.588,48$ \\
\hline 5 & 2023 & $7.713 .829,03$ & $554.814,31$ \\
\hline 6 & 2024 & $7.159 .014,73$ & $575.040,13$ \\
\hline 7 & 2025 & $6.583 .974,60$ & $595.265,96$ \\
\hline 8 & 2026 & $5.988 .708,64$ & $615.491,78$ \\
\hline 9 & 2027 & $5.373 .216,86$ & $635.717,61$ \\
\hline 10 & 2028 & $4.737 .499,25$ & $655.943,43$ \\
\hline 11 & 2029 & $4.081 .555,82$ & $676.169,26$ \\
\hline 12 & 2030 & $3.405 .386,56$ & $696.395,08$ \\
\hline 13 & 2031 & $2.708 .991,47$ & $716.620,91$ \\
\hline 14 & 2032 & $1.992 .370,56$ & $736.846,74$ \\
\hline 15 & 2033 & $1.255 .523,83$ & $499.171,31$ \\
\hline
\end{tabular}

Tabel 19. Prakiraan/forecasting Pasokan dan Kebutuhan Quarry di Kab. Tasikmalaya

\begin{tabular}{|r|r|r|r|}
\hline No & Tahun & $\begin{array}{c}\text { Pasokan/Cadangan } \\
\text { Quarry } \mathbf{( M}^{\mathbf{3}} \mathbf{)}\end{array}$ & Permintaan $\left.\mathbf{( M}^{\mathbf{3}}\right)$ \\
\hline 1 & 2019 & $9.730 .828,00$ & $971.517,56$ \\
\hline 2 & 2020 & $8.759 .310,44$ & $1.012 .980,50$ \\
\hline 3 & 2021 & $7.746 .329,94$ & $1.054 .443,44$ \\
\hline 4 & 2022 & $6.691 .886,50$ & $1.095 .906,38$ \\
\hline 5 & 2023 & $5.595 .980,12$ & $1.137 .369,33$ \\
\hline 6 & 2024 & $4.458 .610,79$ & $1.178 .832,27$ \\
\hline 7 & 2025 & $3.279 .778,52$ & $1.220 .295,21$ \\
\hline 8 & 2026 & $2.059 .483,31$ & $1.261 .758,15$ \\
\hline 9 & 2027 & $797.725,16$ & $1.303 .221,10$ \\
\hline 10 & 2028 & $-505.495,94$ & $1.344 .684,04$ \\
\hline 11 & 2029 & $-1.850 .179,98$ & $1.386 .146,98$ \\
\hline 12 & 2030 & $-3.236 .326,96$ & $1.427 .609,92$ \\
\hline 13 & 2031 & $-4.663 .936,88$ & $1.469 .072,87$ \\
\hline 14 & 2032 & $-6.133 .009,75$ & $1.510 .535,81$ \\
\hline 15 & 2033 & $-7.643 .545,56$ & $1.023 .301,19$ \\
\hline
\end{tabular}

Untuk kebutuhan pembangunan infrastruktur yang ada di Kabupaten/Kota Tasikmalaya dan diluar Kabupaten/Kota Tasikmalaya, pasokan 
agregat/cadangan tambang yang terkira dapat diprakirakan akan defisit pada tahun 2028.

\section{Model Rantai Pasok Bahan Tambang di Kabupaten Tasikmalaya}

Dari hasil survei dan wawancara berkaitan dengan rantai pasok bahan/material sebagai input yang siap untuk digunakan dalam pelaksanaan pekerjaan konstruksi dapat digambarkan sebagaimana Gambar 6.

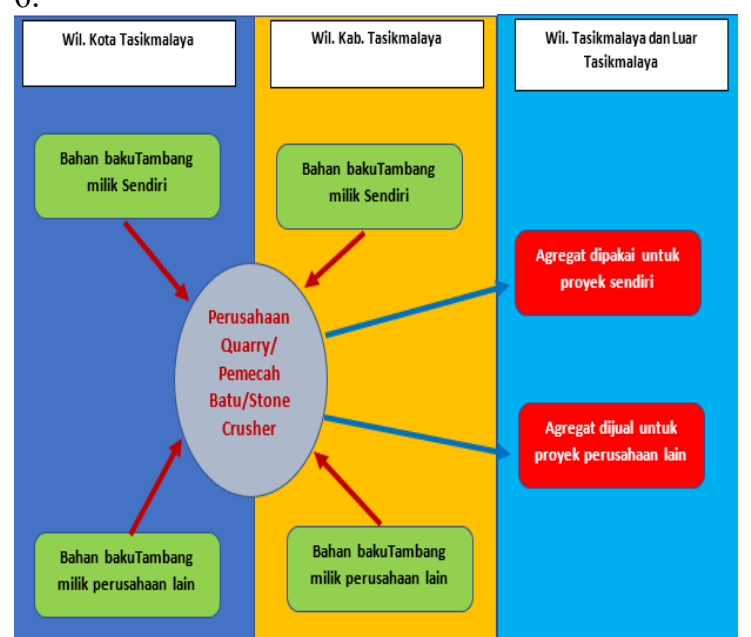

Gambar 6. Model Rantai Pasok Material tambang Kab Tasikmalaya

\section{Pola Interaksi Pihak-pihak Pada Usaha Jasa} Konstruksi

Berdasarkan hasil observasi di lapangan, diperoleh model interaksi rantai pasok usaha jasa konstruksi seperti ditunjukkan pada Gambar 7.

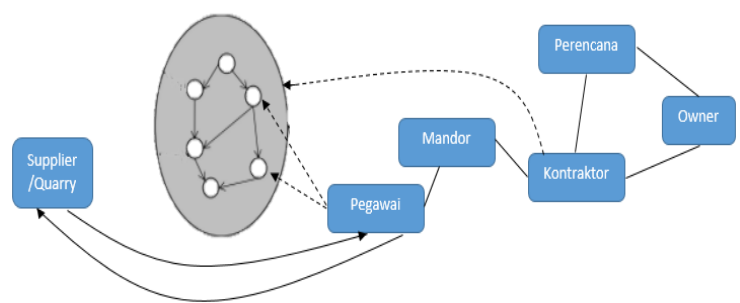

Gambar 7. Model Interaksi Rantai Pasok Eksisting Usaha Jasa Konstruksi

Gambar 7 merupakan hasil dari elaborasi model supply chain yang dikembangkan oleh O'Brien (2002) dengan keadaan eksisting di Kabupaten Tasikmalaya. Dari gambar tersebut dapat diketahui bahwa hubungan yang dimiliki oleh kontraktor dan supplier bersifat tidak langsung. Sehingga informasi ketersediaan bahan dan delivery bahan menjadi tidak optimal. Rantai pasok material usaha jasa konstruksi yang ada di Kabupaten Tasikmalaya agak berbeda dengan konsep rantai pasok yang dikemukakan oleh O'Brien. Disini tidak terdapat kerjasama antara pihak kontraktor dan supplier/quarry. Pihak kontraktor hanya mengirimkan pegawainya untuk membeli sumber daya, sehingga sumber daya yang dibeli dari supplier tidak mengatasnamakan perusahaan, melainkan atas nama pribadi pegawai tersebut. Ini dikarenakan beberapa aspek, diantara-Nya :

1. Pihak kontraktor tidak mendatangi langsung pihak supplier untuk bekerjasama

2. Pihak kontraktor berasumsi bahwa tidak akan ada kekurangan sumber daya selama proyek berjalan

3. Pihak supplier tidak menerima kontrak kerjasama supply dikarenakan uang yang akan diterima ada di akhir pekerjaan, sedangkan hampir semua supplier di Kabupaten Tasikmalaya menginginkan sistem "Ada uang ada barang".

Adapun model interaksi yang ideal adalah sebagaimana Gambar 8.

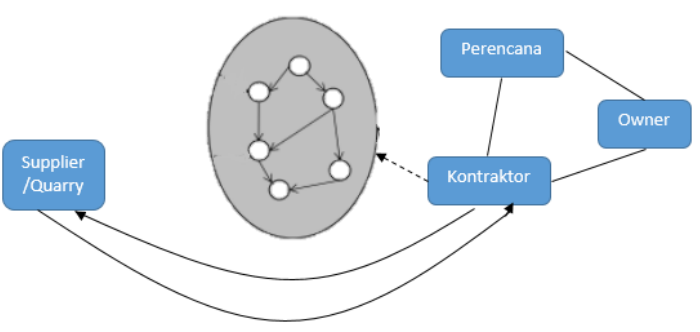

Gambar 8. Pola Rantai Pasok Ideal

Pada Gambar 8 terlihat bahwa kontraktor dan supplier melakukan kerjasama dalam menyelesaikan suatu proyek. Kerjasama tersebut akan meliputi penjadwalan delivery material, pengalokasian material serta kesepakatan harga dan pembayaran material. Apabila kerjasama tersebut berjalan, maka keterlambatan bahan baku akan teratasi.

\section{KESIMPULAN}

Analisis dan bahasan yang dilakukan berdasarkan kerangka kajian yaitu kajian rantai pasok usaha jasa konstruksi Kabupaten Tasikmalaya. Teknik kajian yang dilakukan dengan mengidentifikasi beberapa aspek yang ditinjau pada setiap komponen rantai pasok pelaksanaan proyek. Kajian dilakukan pada tingkat Dinas dan pada tingkat pelaksanaan kegiatan yaitu penyedia jasa konstruksi sebagai rekanan Dinas Pekerjaan Umum dan Penataan Ruang. Dari kajian dan identifikasi penerapan rantai pasok usaha jasa konstruksi di Kabupaten Tasikmalaya diperoleh halhal sebagai berikut:

1. Rantai pasok material alam dalam pekerjaan konstruksi Kabupaten Tasikmalaya tidak sesuai dengan rantai pasok ideal.

2. Untuk meningkatkan efisiensi dan efektivitas dalam pelaksanaan usaha jasa konstruksi di Kabupaten Tasikmalaya, perlu dilakukan perubahan pada model rantai pasok eksisting saat ini dengan model rantai pasok ideal yang telah dibuat pada bagian analisis.

3. Strategi partnership harus didorong diantara para penyedia jasa daerah dengan pemakai peralatan konstruksi dengan sistem sewa alat 
yang mempertimbangkan kemampuan alat dan waktu. Sedangkan strategi partnership pemasok material lokal dan non lokal dilakukan ketika penyedia jasa akan mengikuti pelelangan.

4. Hubungan kerja yang terbangun antara suplier dengan kontraktor utama masih berdasarkan saling kepercayaan antar individu pelaku usaha belum ada perikatan kerjasama yang baku.

5. Tata kelola hubungan antara suplier dengan kontraktor utama belum tergambar dengan jelas bagaimana bentuk organisasinya, kerangka waktu pemasokan, dan tugas pokok dan fungsi masing-masing pelaku belum terdeskripsikan dengan jelas dan belum tertulis. Kajian lanjutan perlu dilakukan untuk mengetahui perilaku organisasi dalam mengelola hubungan kerja sama tersebut.

\section{DAFTAR PUSTAKA}

Aloini, D., Dulmin, R., Mininno, V., \& Ponticelli, S. (2012). Supply chain Management: a Review of Implementation Risks in the Construction Industry. Business Process Management Journal, 18(5), 735-761.

Behera, P., Mohanty, R. P., \& Prakash, A. (2015). Understanding Construction Supply chain Management. Production Planning \& Control, 26(16), 1332-1350.

Chopra, Sunil Meindl, Peter. (2004), Supply chain Management, Pearson Education.New Jersey.

Fearne and Fawler. (2006). Efficiency versus effectiveness in construction supply chains: The dangers of "lean" thinking in isolation. Supply chain Management, Vol.11, No.4, 2006

Harland, C. M. (1996). Supply Chain Management: Relationships, Chains And Network.

Hatmoko, J. U. D., \& Scott, S. (2010). Simulating the Impact of Supply chain Management Practice on the Performance of Medium- Sized Building Projects. Construction Management and Economics, 28(1), 35-49.

O’Brien, W.J., London, K. \& Vrijhoef, R. (2002). Construction Supply chain Modeling: a Research Review and Interdisciplinary Research Agenda. Journal

Suraji, Akhmad dan Rona Dirohanta. (2012), Rantai Pasok Konstruksi Di Sektor Gedung, Universitas Andalas. Padang.

Vrijhoef, R And L Koskela (1999), "Roles Of Supply chain Management In Construction", Proceedings IGLC-7, University Of California, Berkeley.

Vrijhoef, R., \& Koskela, L. (2000). "The Four Roles of Supply chain Management in Construction". European Journal of Purchasing \& Supply Management. Vol. 6, 169-178.

Xue, X., Li, X., Shen, Q., \& Wang, Y. (2005). An Agent-Based Framework for Supply chain
Coordination in Construction. Automation in Construction, 14(3), 413-430 